Print ISSN: 2288-4637 / Online ISSN 2288-4645

doi:10.13106/jafeb.2020.vol7.no9.001

\title{
Diversification and Performance of Sri Lankan Banks
}

\author{
Anirut PISEDTASALASAI ${ }^{1}$, Piyadasa EDIRISURIYA ${ }^{2}$
}

Received: July 03, 2020 Revised: July 25, 2020 Accepted: August 10, 2020

\begin{abstract}
The purpose of this study is to investigate the relationship between diversification and the performance of commercial banks, while taking into account the ownership status of these banks in Sri Lanka. Two-way relationship between diversification and performance was scrutinised by employing the 2SLS regression technique. The data consists of 17 registered commercial bank in Sri Lanka between 20012016. The results show a strong significant bidirectional relationship exists between diversification and bank performance. The performance of Sri Lankan banks has been significantly improved by their diversification attempts. In other words, the banks whose incomes are more diversified from various sources, they are more profitable and successful in long-term. On the other hands, the results also reveal that bank performance positively and significantly affects diversification. This finding suggests that the banks with great profitability are more capable in diversify their operations. Furthermore, private sector banks, both listed and unlisted, are significantly more diversified than their government-owned counterparts, but their performance is not necessarily superior to government-owned banks. This may be the result of the economic environment and the perception of the public, which have allowed the government-owned banks to entertain significant market power over the private sector banks in the country.
\end{abstract}

Keywords: Bank Diversification, Bank Performance, Government Ownership, Sri Lanka, Banking System

JEL Classification Code: E44, G10, G15, G21

\section{Introduction}

Financial deregulation has encouraged commercial banks in many countries to diversify their business activities across a range of functions, such as securitiesrelated activities, insurance, foreign exchange, derivatives, investment management, financial planning and many other off-balance sheet activities, rather than relying on traditional loan making business. This contradicts the popular argument that corporate diversification - conglomerate diversification in particular-reduces rather than enhances firm value.

${ }^{1}$ First Author and Corresponding Author. Assistant Professor, Department of Banking and Finance, Faculty of Commerce and Accountancy, Chulalongkorn University, Thailand [Postal Address: Phayathai Road, Patumwan, Bangkok, 10330, Thailand] Email: anirut@cbs.chula.ac.th

${ }^{2}$ Lecturer, Monash Business School, Monash University, Australia. Email: piyadasa.edirisuriya@monash.edu

(C) Copyright: The Author(s)

This is an Open Access article distributed under the terms of the Creative Commons Attribution Non-Commercial License (https://creativecommons.org/licenses/by-nc/4.0/) which permits unrestricted non-commercial use, distribution, and reproduction in any medium, provided the original work is properly cited.
According to Jensen (1986) free cash flow theory, managers of firms with high level of free cash flows and unused debt capacities tend to diversify their businesses beyond optimum levels with the objective of maximising their personal benefits at the expense of shareholders' wealth. The capital market, therefore, penalises diversification activities while rewarding focus increasing attempts (for example, Kaplan \& Weisbach, 1992; John \& Ofek, 1995). So why do the commercial banks diversify their businesses? Is there a relationship between diversification and the performance of commercial banks? A number of studies provide theoretical arguments both for and against these questions; the empirical evidence is also mixed. Moreover, the investigation of the relationship between bank diversification and performance is mainly limited to regions with developed financial systems, such as the USA, Europe and Japan. The question of whether these relationships exist in recently liberalised financial systems remains largely under-investigated.

The purpose of our study is to investigate the relationship between diversification and the performance of commercial banks, while taking into account the ownership status of these banks, using the data for a recently liberalised small economy, Sri Lanka. As we explain in a later section, 
Sri Lanka was the first country in South Asia to implement a programme of economic and financial deregulation. These deregulation processes not only transformed the banking sector of the country, but also provided opportunities for commercial to engage in non-traditional business activities and thereby have diversified businesses. Most of the banks with countrywide branch networks are owned either by the government or by the private sector. The operations of foreign banks are confined to the main business city of Colombo. An interesting feature of private banks is that, except for recently established banks, all the banks owned by the private sector are listed on the Colombo stock exchange. A few government-owned banks are also listed. This unique ownership structure can have an intervening influence on the relationship between diversification and performance, as the motivation for diversification can vary across these categories of ownership. We are therefore motivated to address the following questions: (1) Is there a relationship between diversification and the performance of Sri Lankan banks? (2) Is this relationship moderated by the ownership of these banks?

\section{Literature Review}

\subsection{Impact of Diversification on Performance of Banks}

It has been argued that diversified banks that engage in a variety of functions could benefit from the economies of scale and, consequently, improve their performance. These banks could achieve allocational efficiency through the internal capital markets available in financial conglomerates (Stein, 1997; Tabash, 2019; Binh \& Nguyen, 2020). Diamond (1984) finds that diversification reduces a bank's monitoring costs while Boyd and Prescott (1986) argue that a bank needs to be diversified as much as possible in order to optimise its value. Baele, De Jonghe and Vander Vennet (2007) report that income diversification is associated with positive longterm performance of banks in 17 European countries. Rossi, Schwaiger and Winkler (2009) report that diversification lowers bank risk, decreases cost efficiency and increase profit efficiency of Australian banks. Elsas, Hackethal and Holzhauser (2010) confirms the diversification has a positive influence on bank profitability in the U.S. and major European countries. Lee, Hsieh and Yang (2014) study 29 Asia-Pacific markets and show that a strategy of diversification enhances bank profitability from various channels while risk of the revenues is reduced. However, this result is predominantly observed in a bank-based system rather than in a market-based system. Moudud-UI-Huq, Ashraf, Gupta and Zheng (2018) investigate the impact of income and asset diversification on bank performance and risk in five ASEAN economies. Both income and asset diversification improves bank performance but reduces risk in Indonesia and Thailand. In the Philippines, Vietnam, and Malaysia, banks also benefits from income diversification but the benefits form asset diversification are mixed. Improving in bank performance is driven by commission income, trading income and other incomes. Sarwar, Muhammad and Zaman (2020) report that diversification of Pakistani banks is associated with bank margin. Khan, Hassan, Maroney, Boujlil and Ozkan (2020) examines efficiency and performance of the US banks in diversifying their operations into various financial services. They report a diversification premium implying bank diversification generates an excess value to banks although the impact on efficiency of bank is mixed.

However, an opposing argument is that functional diversification could affect bank performance negatively, as it could aggravate the agency problem of a financial conglomerate. Laeven and Levine (2007) argue that the opaqueness of financial conglomerates make them difficult to monitor; therefore, a diversified bank could be prone to agency conflicts not only between insiders and outsiders, but also between the head office and divisional managers, among its divisions and between the bank and its customers. Stiroh and Rumble (2006) find that even though the diversification is beneficial to U.S. bank holding companies, these gains are offset by the increased exposure to non-interest activities, which are much more volatile but not necessarily more profitable than interest-generating activities. Mercieca, Schaeck and Wolfe (2007) and Lepeti, Nys, Rous and Tarazi (2008) report that non-interest income increases risk for European banks and this finding is also supported Batten and Vo (2016) providing evidence from Vietnam. DeYong and Roland (2001) and Stiroh (2004) find revenue diversification has a negative impact on the risk-return profile of U.S. banks. Berger, Hasan and Zhou (2009) also show that diversification lowers profits with incurring higher cost for Chinese banks.

\subsection{Impact of Performance on Diversification of Banks}

Despite the attempt of many studies to analyse the impact of diversification on bank performance, the argument of whether the bank performance influences diversification has not been subjected to extensive examination in empirical research. Venzin, Kumar and Kleine (2008), using a micro-level case study methodology, find that the diversification attempts of multinational European banks depend on their performance related attributes, such as product portfolios, branch network configurations, branding strategies, social networks. Baele, De Jonghe and Vander Vennet (2007) argue that financial conglomerates can use the information accessed through 
lending relations to provide other financial services more efficiently, implying that larger banks with better performance might be associated with diversity of their operations. Khan, Hassan, Maroney, Boujlil and Ozkan (2020) examines effects of efficiency and excess value of banks on diversification for publicly traded banks around the world over the period of 2002-2010. They shows that the efficiency and excess value do not cause banks to diversify their businesses.

\subsection{Impact of Ownership Structure on Performance and Diversification of Banks}

A number of studies have investigated the influence of bank ownership on performance. It is a commonly accepted view among researchers that the government-owned banks perform poorly compared to private sector banks due to political interference and their inbuilt inefficiencies ( $\mathrm{La}$ Porta, Lopez-De-Silanes, \& Shleifer, 2002; Micco, Panizza, \& Yañez, 2007). Claessens, Djankov, Fan and Lang (2002) argue that even if a bank is a publicly listed entity, such a bank could look for political benefits rather than efficiency improvements if the largest shareholder is the government. Lin and Zhang (2009) analyse Chinese banks and find that the government-owned commercial banks are less profitable, less efficient and have worse asset quality compared to private sector banks and foreign banks. Similarly, Micco, Panizza and Yañez (2007) find that government-owned banks that operate in developing countries tend to have lower profitability and higher costs than privately owned banks, but foreign banks operating in these countries appear to be more profitable than private banks. A study of Chinese banks by Berger, Hasan and Zhou (2009) reveals that state-owned big four banks are by far the least efficient, and foreign banks are the most efficient. However, Bonin, Hasan and Wachtel (2005) who analysed 229 banks located in transition economies, conclude that privatisation is not sufficient to increase bank efficiency, as government-owned banks are not always less efficient than domestic private banks; however, foreign ownership leads to improved performance of banks in transition countries. With respect to the influence of ownership structure on diversification, Pennathur, Subrahmanyam and Vishwasrao (2012) find that public sector banks with higher levels of governmental ownership are significantly less likely to pursue non-interest income sources or diversification strategies.

\section{Research Methods and Materials}

\subsection{Sample and Data}

Currently, 37 banks conduct banking business in Sri Lanka. They were given the authority to operate as licenced commercial banks by the central bank of Sri Lanka. Out of these banks, we include banks for which the necessary data are available from the Bureau van Dijk BankScope database for at least five consecutive years. A five-year date availability requirement was imposed due to the long-term nature of the diversification decision. The full sample consists of 213 bank-year observations of Seventeen commercial banks fulfilled this requirement; therefore, we concentrated on those banks. This sample represents five government-owned banks, three government-owned listed banks and nine private sector listed banks.

For this sample, we collected the data on an annual basis for the following variables for the period from 2001 to 2016: return on average assets, non-interest income, total income, total assets, book value of equity, total cost, reserves for impaired loans, total loans and the capital adequacy ratio. The data on the rate of inflation and the GDP growth rate were collected from the annual reports of the Central Bank of Sri Lanka.

\subsection{Model Specification}

\subsubsection{Influence of Bank Diversification on Performance}

Our measure of performance is the return on assets $(R O A)$ and the measure of diversification is the ratio of non-interest income to total income (NIITI). In order to understand whether the bank performance is influenced by income diversification, we first estimate the following equation:

$$
\begin{aligned}
& R O A_{i, t}= \propto \\
&+\beta_{1}\left(N I T I_{i, t}\right)+\beta_{2}\left(T A_{i, t}\right)+\beta_{3}\left(E T A_{i, t}\right) \\
&+\beta_{4}\left(C I_{i, t}\right)+\beta_{5}\left(L L P_{i, t}\right)+\beta_{6}\left(G D P_{i, t}\right) \\
&+\beta_{7}\left(I N F_{i, t}\right)+\beta_{8}\left(W A R_{i, t}\right)+\varepsilon_{i, t}
\end{aligned}
$$

From the (1), essentially we check $\beta_{1}$ to test whether diversification will lead to the improved performance of banks. We also control for difference characteristics of banks and macroeconomic conditions that could potential influence the $R O A$ for bank $i$ in time $\mathrm{t}$ (see Baele, De Jonghe, \& Vander Vennet, 2007; Berger, Hasan, \& Zhou, 2009). Those control variables are as follows. $T A$ (i.e. the natural logarithm of total assets) is used to capture size-related influences that stem from differences in size among banks and to control for firm size effects. ETA is the equity to assets (i.e. the book value of equity divided by total assets) capturing the influence of bank capital on firm performance. $C I$ is cost to income (i.e. total cost divided by total income) representing the influence of operational efficiency on bank performance. $L L P$ is the loan loss provision (i.e. the reserves for impaired loans divided by total loans) accounting for the quality of loans in the portfolio of the bank's assets. GDP (i.e. GDP growth 
rate) and $I N F$ (i.e. inflation rate) are designed to capture the macro-economic influence on the performance of banks. WAR is the dummy capturing the impact of separatist war prevailed in some years of the study period.

We then consider whether the influence of NITI on ROA is conditional to the ownership status of a bank. For this purpose, we add a dummy variable representing governmentowned banks, both listed and unlisted and estimate the following model:

$$
\begin{aligned}
R O A_{i, t}=\propto & +\beta_{1}\left(\operatorname{NITI}_{i, t}\right)+\beta_{2}\left(T A_{i, t}\right) \\
& +\beta_{3}\left(E T A_{i, t}\right)+\beta_{4}\left(C I_{i, t}\right) \\
& +\beta_{5}\left(L L P_{i, t}\right)+\beta_{6}\left(G D P_{i, t}\right) \\
& +\beta_{7}\left(I N F_{i, t}\right)+\beta_{8}\left(W A R_{i, t}\right) \\
& +\beta_{9}\left(G O V_{i, t}\right)+\varepsilon_{i, t}
\end{aligned}
$$

where $G O V$ takes the value of one if the bank is a governmentowned entity and zero otherwise. Therefore, $\beta_{0}$ represents the impact of being government-owned banks on the bank performance. We further split government-owned banks into two groups as government-owned unlisted banks (GOVU) and government-owned listed banks (GOVL) and estimate the following equation to investigate if being governmentowned and listed on the stock exchange makes a difference to the above relationship:

$$
\begin{aligned}
R O A_{i, t}=\propto & +\beta_{1}\left(N I T I_{i, t}\right)+\beta_{2}\left(T A_{i, t}\right)+\beta_{3}\left(E T A_{i, t}\right) \\
& +\beta_{4}\left(C I_{i, t}\right)+\beta_{5}\left(L L P_{i, t}\right)+\beta_{6}\left(G D P_{i, t}\right) \\
& +\beta_{7}\left(I N F_{i, t}\right)+\beta_{8}\left(\text { War }_{i, t}\right)+\beta_{9}\left(G O V U_{i, t}\right) \\
& +\beta_{10}\left(G O V L_{i, t}\right)+\varepsilon_{i, t}
\end{aligned}
$$

where GOVU takes the value of 1 if the bank is governmentowned but unlisted and zero otherwise, and GOVL takes the value of 1 if the bank is government-owned and listed on the exchange and zero otherwise.

\subsubsection{Influence of Bank Performance on Diversification}

In this section, the opposite hypothesis to that of section 3.2.1 is investigate. We test whether the income diversification of a bank is influenced by its performance. The following regression is estimated.

$$
\begin{aligned}
\operatorname{NITI}_{i, t}=\propto & +\beta_{1}\left(R O A_{i, t}\right)+\beta_{2}\left(T A_{i, t}\right)+\beta_{3}\left(L T A_{i, t}\right) \\
& +\beta_{4}\left(L L P_{i, t}\right)+\beta_{5}\left(C A P A D_{i, t}\right)+\beta_{6}\left(G D P_{i, t}\right) \\
& +\beta_{7}\left(I N F_{i, t}\right)+\beta_{8}\left(W A R_{i, t}\right)+\varepsilon_{i, t}
\end{aligned}
$$

From the (4), $\beta_{1}$ represents the impact of bank performance on diversification. LTA is the total loans to total assets ratio, and $C A P A D$ is the capital adequacy ratio. The other variables are defined as before. Loans to assets ratio (LTA) captures the influence of the concentration on loan making on diversification while capital adequacy ratio $(C A P A D)$ represents the influence of risk and solvency on the bank on diversification.

We then examine whether the influence of performance on the diversification is conditional to the ownership status of the bank. For this purpose, as modelled it in the previous regressions, the following two equations are estimated:

$$
\begin{aligned}
\operatorname{NITI}_{i, t}=\propto & +\beta_{1}\left(\operatorname{ROA}_{i, t}\right)+\beta_{2}\left(\operatorname{TA}_{i, t}\right)+\beta_{3}\left(L T A_{i, t}\right) \\
& +\beta_{4}\left(L L P_{i, t}\right)+\beta_{5}\left(\operatorname{CAPAD}_{i, t}\right) \\
& +\beta_{6}\left(G D P_{i, t}\right)+\beta_{7}\left(I_{i, t}\right)+\beta_{8}\left(\text { WAR }_{i, t}\right) \\
& +\beta_{9}\left(G O V_{i, t}\right)+\varepsilon_{i, t} \\
\operatorname{NITI}_{i, t}=\propto & +\beta_{1}\left(\operatorname{ROA}_{i, t}\right)+\beta_{2}\left(T A_{i, t}\right) \\
& +\beta_{3}\left(L T A_{i, t}\right)+\beta_{4}\left(L L P_{i, t}\right) \\
& +\beta_{5}\left(\operatorname{CAPAD}_{i, t}\right)+\beta_{6}\left(G D P_{i, t}\right) \\
& +\beta_{7}\left(\operatorname{INF}_{i, t}\right)+\beta_{8}\left(\operatorname{War}_{i, t}\right) \\
& +\beta_{9}\left(\operatorname{GOVU}_{i, t}\right)+\beta_{9}\left(G O V L_{i, t}\right)+\varepsilon_{i, t}
\end{aligned}
$$

\section{Results and Discussion}

\subsection{Sample Characteristics, Diversification and Performance by Bank Ownership}

Table 1 reports descriptive statistics for sample characteristics by bank ownership. An average Sri Lankan bank employed assets worth of 588,187 million rupees with the average of natural logarithm of total assets (TA) of 13.28. Government-owned unlisted banks are the largest banks, followed by private sector listed banks and governmentowned listed banks. Government-owned listed banks seem to maintain a stronger equity base, reporting the highest equity to assets ratio (ETA) of 16.62 per cent, compared to other two categories. The private sector listed banks are the least cost efficient, reporting the highest cost to income ratio (CI) of 67.27 per cent, but they seem to be more efficient in collecting outstanding loans than the other two categories as evinced by the lowest loan loss provision ratio (LLP) of 3.60 per cent. The government-owned banks, both listed and unlisted, maintain a higher capital adequacy ratio than their private sector counterparts. 
Table 1: Sample Characteristics by Bank Ownership

\begin{tabular}{|c|c|c|c|c|c|c|c|}
\hline Type of bank & Statistic & TA & ETA & LTA & $\mathrm{Cl}$ & LLP & CAPAD \\
\hline \multirow[t]{4}{*}{ All banks } & Mean & 13.2846 & 0.1078 & 0.6093 & 0.6146 & 0.0405 & 0.1483 \\
\hline & Std. deviation & 1.3416 & 0.0702 & 0.1230 & 0.1619 & 0.0281 & 0.0472 \\
\hline & Minimum & 10.8837 & 0.0212 & 0.2950 & 0.3253 & 0.0063 & 0.0823 \\
\hline & Maximum & 15.2231 & 0.2602 & 0.8345 & 0.9554 & 0.1162 & 0.2615 \\
\hline \multirow[t]{4}{*}{ GOVU } & Mean & 14.2657 & 0.0854 & 0.5576 & 0.5648 & 0.0493 & 0.1542 \\
\hline & Std. deviation & 1.1003 & 0.0726 & 0.1618 & 0.1718 & 0.0396 & 0.0580 \\
\hline & Minimum & 11.3826 & 0.0212 & 0.2950 & 0.3253 & 0.0063 & 0.0823 \\
\hline & Maximum & 15.2231 & 0.2602 & 0.8345 & 0.9554 & 0.1162 & 0.2615 \\
\hline \multirow[t]{4}{*}{ GOVL } & Mean & 12.4154 & 0.1662 & 0.6630 & 0.5008 & 0.0407 & 0.1617 \\
\hline & Std. deviation & 1.0634 & 0.0567 & 0.1150 & 0.1680 & 0.0219 & 0.0474 \\
\hline & Minimum & 10.8837 & 0.0212 & 0.4013 & 0.3253 & 0.0087 & 0.0823 \\
\hline & Maximum & 14.1303 & 0.2602 & 0.8345 & 0.9554 & 0.0996 & 0.2615 \\
\hline \multirow{4}{*}{$\begin{array}{l}\text { Private sector } \\
\text { listed banks }\end{array}$} & Mean & 13.0538 & 0.1017 & 0.6192 & 0.6727 & 0.0360 & 0.1415 \\
\hline & Std. deviation & 1.2465 & 0.0636 & 0.0905 & 0.1263 & 0.0212 & 0.0397 \\
\hline & Minimum & 10.8837 & 0.0212 & 0.2950 & 0.4059 & 0.0063 & 0.0823 \\
\hline & Maximum & 15.2095 & 0.2602 & 0.8345 & 0.9554 & 0.1162 & 0.2615 \\
\hline
\end{tabular}

Table 2: Comparison of Diversification and Performance by Bank Ownership

\begin{tabular}{|l|l|c|c|c|c|l|}
\hline Variable & \multicolumn{1}{|c|}{ Statistic } & All banks & GOVU & GOVL & $\begin{array}{l}\text { Private sector } \\
\text { listed banks }\end{array}$ & \multicolumn{1}{|c|}{ Test statistic } \\
\hline \multirow{2}{*}{$\begin{array}{l}\text { Non-interest } \\
\text { income to total } \\
\text { income (NIITI) }\end{array}$} & Mean & 0.3274 & 0.2758 & 0.3304 & 0.3522 & F statistic $=5.67^{* * * *}$ \\
\cline { 2 - 7 } & Median & 0.3304 & 0.2876 & 0.3330 & 0.3377 & Kruskal-Wallis statistic $=10.18^{* * *}$ \\
\cline { 2 - 7 } & Std. deviation & 0.1283 & 0.1454 & 0.0547 & 0.2423 & Levene statistic $=5.01^{* * *}$ \\
\hline \multirow{2}{*}{$\begin{array}{l}\text { Return on assets } \\
\text { (ROA) }\end{array}$} & Mean & 0.0151 & 0.0128 & 0.0207 & 0.0145 & F statistic $=3.76^{* *}$ \\
\cline { 2 - 7 } & Median & 0.0127 & 0.0101 & 0.0214 & 0.0120 & Kruskal-Wallis statistic $=12.14^{* * *}$ \\
\cline { 2 - 7 } & Std. deviation & 0.0140 & 0.0121 & 0.0148 & 0.0143 & Levene statistic $=0.75$ \\
\hline
\end{tabular}

Table 2 compares diversification and performance among banks based on their ownership status. Private sector listed banks generate a highest proportion of income from non-interest sources (mean $=35$ per cent; median $=33$ per cent). The non-interest income proportion of governmentowned listed banks (a mean/median ratio of per cent) is slightly lower than that reported by private sector banks; this ratio for the government-owned unlisted banks remain at a much lower level $($ mean $=28$ per cent; median $=29$ per cent). Clearly, banks listed on the stock exchange and owned either by the government or the private sector investors seem to take the advantage of opportunities provided by the deregulated financial system and offer diversified products to their customers than those totally owned by the government. This may be the result of listed banks being monitored by the investment community, which forces them to make use of opportunities available in the deregulated economy. We observe a similar picture with respect to the performance of these banks. The best performing banks are the government-owned listed banks; they report an average ROA of 2.07 per cent followed by the private sector listed banks ( 1.45 per cent) and government-owned unlisted banks (1.28 per cent). The statistics reported in the last column of Table 2 reveal that statistically significant differences exist among the three groups of banks with respect to both diversification and performance. Such a finding provides strong motivation to investigate the relationship between diversification and performance subject to the ownership status of Sri Lankan banks. This is addressed in the next sections. 


\subsection{The Effect of Bank Diversification on Performance}

Table 3 reports the estimates of regression equations (1) to (3). Clearly, Sri Lankan banks have benefitted from income diversification; the coefficient on NITI is positive (ranging from 0.0086 to 0.0095 ) and significant at the 5 per cent level in all three models estimated. However, the governmentowned bank ( $G O V$ ) dummy in column 2 enters into equation (2) with a negative coefficient $(-0.0055)$, which is significant at the 5 per cent level. This implies that, compared to their private sector counterparts, government-owned banks underperform in terms of profitability by a significant margin. When these government-owned banks were disaggregated into two groups as government-owned unlisted (GOVU) banks and government-owned listed (GOVL) banks, the results reported in column 3 reveal that the GOVU dummy enters into equation (3) is negative and significant, while the GOVL dummy is not statistically significant. This finding clearly indicates that the profitability performance of government-owned listed banks is not dissimilar to that of private sector listed banks, but government-owned unlisted banks demonstrate a significant underperformance. Turning to control variables, we find that the coefficients of equity to assets ratio are positive and significant in all three models estimated, implying that well-capitalised banks are generally associated with better performance. The size of the bank does not have any influence on bank performance, however. On the other hand, costs to income and loan loss provisions have negative influences on bank ROA; banks that are inefficient in managing their costs and those that are generous in providing loans (and therefore have to allocate a high portion of their income to loan loss provisions) are less effective in achieving higher profitability. Among macroeconomic factors, we find that the rate of inflation has a significant negative influence on bank profitability. High inflation is normally associated with high interest rates in the economy, and this discourages borrowers having a negative influence on bank performance. Not surprisingly, we find that WAR dummy enters into regression models with negative and significant coefficients; the contraction of economic activities during the war period had a negative impact on bank profitability. The model $\mathrm{R}^{2}$ values are high ranging between 53 per cent and 55 per cent, and the model F-statistics are significant at the 1 per cent level.

Table 3: The Effect of Bank Diversification on Performance

\begin{tabular}{|c|c|c|c|}
\hline Independent Variable & Equation (1) & Equation (2) & Equation (3) \\
\hline Constant & $\begin{array}{c}0.0145 \\
(1.29)\end{array}$ & $\begin{array}{c}0.0167 \\
(1.42)\end{array}$ & $\begin{array}{c}0.0176 \\
(1.23)\end{array}$ \\
\hline Non-interest income to total income (NIITI) & $\begin{array}{c}0.0095^{\star *} \\
(2.53)\end{array}$ & $\begin{array}{c}0.0093^{\text {** }} \\
(2.03)\end{array}$ & $\begin{array}{c}0.0086^{\text {** }} \\
(2.00)\end{array}$ \\
\hline Natural logarithm of total assets (TA) & $\begin{array}{c}0.0007 \\
(0.97)\end{array}$ & $\begin{array}{c}0.0008 \\
(1.11)\end{array}$ & $\begin{array}{c}0.0008 \\
(0.83)\end{array}$ \\
\hline Equity to assets (ETA) & $\begin{array}{c}0.0862^{\star \star \star} \\
(7.56)\end{array}$ & $\begin{array}{c}0.0893^{* * *} \\
(7.67)\end{array}$ & $\begin{array}{c}0.0861^{\star \star \star} \\
(7.22)\end{array}$ \\
\hline Cost to income $(\mathrm{Cl})$ & $\begin{array}{c}-0.0310^{* * *} \\
(-7.15)\end{array}$ & $\begin{array}{c}-0.0328^{* * *} \\
(-5.45)\end{array}$ & $\begin{array}{c}-0.0328^{* * *} \\
(-5.11)\end{array}$ \\
\hline Loan loss provision (LLP) & $\begin{array}{c}-0.0365^{*} \\
(-1.92)\end{array}$ & $\begin{array}{c}-0.0311 \\
(-1.54) \\
\end{array}$ & $\begin{array}{r}-0.0332^{*} \\
(-1.63)\end{array}$ \\
\hline GDP growth rate (GDP) & $\begin{array}{c}0.0445 \\
(1.21)\end{array}$ & $\begin{array}{c}0.0413 \\
(1.11)\end{array}$ & $\begin{array}{c}0.0412 \\
(1.06)\end{array}$ \\
\hline Rate of inflation (INF) & $\begin{array}{c}-0.0149^{*} \\
(-1.78)\end{array}$ & $\begin{array}{c}-0.0139^{*} \\
(-1.80)\end{array}$ & $\begin{array}{c}-0.0143^{*} \\
(-1.84)\end{array}$ \\
\hline War period dummy (WAR) & $\begin{array}{c}-0.0026^{* *} \\
(-2.57) \\
\end{array}$ & $\begin{array}{c}-0.0027^{\star *} \\
(-2.28)\end{array}$ & $\begin{array}{c}-0.0027^{\star *} \\
(-2.22)\end{array}$ \\
\hline Government-owned bank dummy (GOV) & & $\begin{array}{c}-0.0055^{\star *} \\
(-2.26)\end{array}$ & \\
\hline Government-owned unlisted bank dummy (GOVU) & & & $\begin{array}{c}-0.0058^{* *} \\
(-2.55) \\
\end{array}$ \\
\hline Government-owned listed bank dummy (GOVL) & & & $\begin{array}{c}-0.0051 \\
(-1.04) \\
\end{array}$ \\
\hline R-squared & 0.53 & 0.55 & 0.54 \\
\hline Model F-statistic & $28.59^{* * *}$ & $27.55^{\star * \star}$ & $23.75^{* * *}$ \\
\hline Number of observations & 213 & 213 & 213 \\
\hline
\end{tabular}

Note: ${ }^{* *},{ }^{* *}$ and ${ }^{*}$ indicates significant at $1 \%, 5 \%$ and $10 \%$ levels, respectively. The t-statistics are reported in parentheses. 


\subsection{The Effect of Bank Performance on Diversification}

In this section, we investigate whether income diversification is influenced by bank performance and, if so, whether the influence of performance on diversification is conditional on the ownership status of a bank. For this purpose, regression equations (4) to (6) are estimated, and the resultant outputs are reported in Table 4 . The coefficients of the $R O A$ variable are positive (ranging from 2.2253 to 2.4160 ) and significant at the 1 per cent level, implying that highly profitable banks have a tendency to achieve a high level of diversification in their income. However, as reported in column 2, the GOV dummy enters into equation (5) with a negatively significant coefficient, implying that government-owned banks are significantly less diversified than their private sector counterparts. When the government-owned banks are split into two groups as unlisted and listed, we find that this negative influence stems from $G O V U$, as implied by the significant negative coefficient generated for the GOVU dummy. The income diversification of GOVL is not significantly different from that of private sector listed banks. Turning to control variables, we find that both bank size and capital adequacy ratio generate negative and significant coefficients implying that large banks and those that maintain a high capital adequacy ratio tend to diversify their income less. The macro-economic variables as well as the war period do not have any significant impact on income diversification attempts of these banks.

Table 4: The Effect of Bank Performance on Diversification

\begin{tabular}{|c|c|c|c|}
\hline Independent Variable & Equation (4) & Equation (5) & Equation (6) \\
\hline Constant & $\begin{array}{c}0.7920^{* * * *} \\
(5.33)\end{array}$ & $\begin{array}{c}0.7492^{* * *} \\
(5.18)\end{array}$ & $\begin{array}{c}0.7612^{* * *} \\
(4.89)\end{array}$ \\
\hline Return on assets (ROA) & $\begin{array}{c}2.3274^{\text {t*t* }} \\
(2.95)\end{array}$ & $\begin{array}{c}2.4160^{* * *} \\
(3.16)\end{array}$ & $\begin{array}{c}2.2253^{* * * *} \\
(2.78)\end{array}$ \\
\hline Natural logarithm of total assets (TA) & $\begin{array}{c}-0.0234^{* *} \\
(-2.48)\end{array}$ & $\begin{array}{c}-0.0207^{* *} \\
(-2.27)\end{array}$ & $\begin{array}{c}-0.0201^{* *} \\
(-1.96)\end{array}$ \\
\hline Loans to assets (LTA) & $\begin{array}{r}-0.1307 \\
(-1.60)\end{array}$ & $\begin{array}{c}-0.1087 \\
(-1.36)\end{array}$ & $\begin{array}{c}-0.1288 \\
(-1.57)\end{array}$ \\
\hline Loan loss provisions (LLP) & $\begin{array}{c}-0.1698 \\
(-0.51)\end{array}$ & $\begin{array}{c}-0.0454 \\
(-0.14)\end{array}$ & $\begin{array}{c}-0.1205 \\
(-0.36)\end{array}$ \\
\hline Capital adequacy ratio (CAPAD) & $\begin{array}{c}-0.6200^{* * * *} \\
(-3.00)\end{array}$ & $\begin{array}{c}-0.5405^{\text {*** }} \\
(-2.64)\end{array}$ & $\begin{array}{c}-0.5514^{\text {**t* }} \\
(-2.62)\end{array}$ \\
\hline GDP growth rate (GDP) & $\begin{array}{r}-0.5507 \\
(-0.87) \\
\end{array}$ & $\begin{array}{r}-0.5740 \\
(-0.91) \\
\end{array}$ & $\begin{array}{c}-0.5674 \\
(-0.89) \\
\end{array}$ \\
\hline Rate of inflation (INF) & $\begin{array}{c}0.1905 \\
(1.29)\end{array}$ & $\begin{array}{c}0.1980 \\
(1.34)\end{array}$ & $\begin{array}{c}0.1990 \\
(1.34)\end{array}$ \\
\hline War period dummy (WAR) & $\begin{array}{c}0.0030 \\
(0.17)\end{array}$ & $\begin{array}{c}0.0039 \\
(0.21)\end{array}$ & $\begin{array}{l}0.0025 \\
(0.14)\end{array}$ \\
\hline Government owned bank dummy (GOV) & & $\begin{array}{c}-0.0541^{* *} \\
(-2.03) \\
\end{array}$ & \\
\hline Government owned unlisted bank dummy (GOVU) & & & $\begin{array}{c}-0.0611^{*} \\
(-1.77) \\
\end{array}$ \\
\hline Government owned listed bank dummy (GOVL) & & & $\begin{array}{c}-0.0443 \\
(-1.12) \\
\end{array}$ \\
\hline R-squared & 0.09 & 0.11 & 0.10 \\
\hline Model F-statistic & $2.50^{* *}$ & $2.72^{* * *+}$ & $2.34^{* *}$ \\
\hline Number of observations & 213 & 213 & 213 \\
\hline
\end{tabular}

Note: ${ }^{* *},{ }^{* *}$ and ${ }^{*}$ indicates significant at $1 \%, 5 \%$ and $10 \%$ levels, respectively. The t-statistics are reported in parentheses. 


\subsection{Two-way Relationship of Diversification and Performance}

The analyses conducted so far point to a possible causality between ROA and NITI. In equations (1) to (3), the NIITI variable generates positive and significant coefficients, while in equations (4) to (6), the $R O A$ variable generates positive and significant coefficients. In order to take into account this possible causal effect, in this section, we estimate equations (3) and (6) simultaneously by employing 2SLS methodology. Our objectives here are to examine (i) whether there is a causal relationship between diversification and performance and (ii) whether the influence of bank ownership status on the performance-diversification relationship holds even after controlling for this possible the two-way relationship. The output of 2SLS regression is reported in Table 5. Both NITI and $R O A$ coefficients remain positive and significant, implying a causal relationship between these two variables; greater diversification is associated with higher profitability, and higher performance is associated with greater diversification. The influence of control variables on performance remain similar to what we observed before. The only exceptions are the significant positive coefficients generated for bank size and GDP growth in ROA regression implying that bank size and economic expansion have positive influences on bank performance.

Table 5: 2SLS Regression Estimates

\begin{tabular}{|c|c|c|}
\hline Independent Variable & Equation (3) & Equation (6) \\
\hline Constant & $\begin{array}{c}-0.0262^{* *} \\
(-2.18)\end{array}$ & $\begin{array}{c}0.4313^{\star \star *} \\
(3.25)\end{array}$ \\
\hline Non-interest income to total income (NIITI) & $\begin{array}{c}0.0960^{* *} \\
(2.53)\end{array}$ & \\
\hline Return on assets (ROA) & & $\begin{array}{c}2.9121^{* * *} \\
(3.51)\end{array}$ \\
\hline Natural logarithm of total assets (TA) & $\begin{array}{c}0.0014^{* *} \\
(2.26)\end{array}$ & $\begin{array}{c}-0.0092 \\
(-1.17)\end{array}$ \\
\hline Equity to assets (ETA) & $\begin{array}{c}0.0846^{* * *} \\
(3.21)\end{array}$ & \\
\hline Cost to income $(\mathrm{Cl})$ & $\begin{array}{c}-0.0324^{* * *} \\
(-5.75)\end{array}$ & \\
\hline Loan loss provisions (LLP) & $\begin{array}{c}-0.0320 \\
(-1.12) \\
\end{array}$ & $\begin{array}{c}0.5831^{*} \\
(1.75)\end{array}$ \\
\hline Loans to assets (LTA) & & $\begin{array}{c}0.0510 \\
(0.66) \\
\end{array}$ \\
\hline Capital adequacy ratio (CAPAD) & & $\begin{array}{c}-0.2169 \\
(-1.05) \\
\end{array}$ \\
\hline GDP growth rate (GDP) & $\begin{array}{c}0.1077^{\star *} \\
(2.01)\end{array}$ & $\begin{array}{c}-0.8061 \\
(-1.09)\end{array}$ \\
\hline Rate of inflation (INF) & $\begin{array}{c}-0.0250^{*} \\
(-1.78) \\
\end{array}$ & $\begin{array}{c}0.1989 \\
(1.11) \\
\end{array}$ \\
\hline War period dummy (WAR) & $\begin{array}{c}-0.0029^{* *} \\
(-2.23)\end{array}$ & $\begin{array}{c}0.0106 \\
(0.49)\end{array}$ \\
\hline Government owned unlisted bank dummy (GOVU) & $\begin{array}{c}0.0020 \\
(0.65) \\
\end{array}$ & $\begin{array}{c}-0.0610^{* * *} \\
(-2.73) \\
\end{array}$ \\
\hline Government owned listed bank dummy (GOVL) & $\begin{array}{c}-0.0020 \\
(-0.80)\end{array}$ & $\begin{array}{c}-0.0446^{*} \\
(-1.83)\end{array}$ \\
\hline R-squared & 0.73 & 0.15 \\
\hline Model F-statistic & $55.02^{* * *}$ & $3.53^{* * *}$ \\
\hline Number of observations & 213 & 213 \\
\hline
\end{tabular}

Note: ${ }^{* *},{ }^{* *}$ and ${ }^{*}$ indicates significant at $1 \%, 5 \%$ and $10 \%$ levels, respectively. The t-statistics are reported in parentheses. 
In our NITI regression of 2SLS system, all the control variables except loan loss provision remain insignificant, implying that both bank-specific and macro-economic variables do not have any significant impact on diversification activities of these banks; diversification is affected solely by the performance of the bank. The influence of ownership status of banks on both performance and diversification alters when the equations are estimated simultaneously. Relative to their private sector listed counterparts, governmentowned banks, both listed and unlisted, are significantly less diversified - both the GOVU and GOVL dummies generate negative and significant coefficients $(-0.0610$ and -0.0446$)$ in NITI regression. However, the performance of private sector listed banks is not significantly different from those of government-owned listed and unlisted banks.

In ROA regression, both GOVU and GOVL dummies generate insignificant coefficients. The emerging conclusion from this analysis is that, even though private sector listed banks grabbed the opportunities provided by the liberalised economy by diversifying their business activities into noninterest generating sources. However, this transformation has not necessarily improved their profitability performance by a significant margin.

\subsection{Discussion}

Taken together, our analyses provide three main findings: (i) there is a bidirectional relationship between diversification and performance of Sri Lankan banks, (ii) privates sector banks are significantly more diversified than government-owned (both listed and unlisted) banks and (iii) the performance of government-owned banks (both listed and unlisted) is not dissimilar from that of private sector banks. All these relationships are plausible for a number of reasons. First, the two-way relationship between diversification and performance is justifiable, since the analyses are conducted for the most recent years of the post-deregulatory period in which banks were offered opportunities to diversify their sources of income and improve performance. Second, the government-owned banks are less diversified than private sector banks since they tend to pursue political objectives. Many senior officers of government-owned banks are appointed by the government; therefore, the government has a significant influence on the policy decisions of these banks. For example, many government-sponsored credit and investment programmes are implemented through these banks, and these banks are expected to give high priority to government-sponsored programmes. This inhibits their motivation to generate a substantial income from non-loan sources. As Claessens, Djankov, Fan and Lang (2002) argue, even if a bank is a listed entity, if the largest shareholder is the government, the government could look for political benefits rather than efficiency improvements. Finally, the performance of private sector banks is not dissimilar to government-owned banks because of the market power entertained by governmentowned banks. Irrespective of financial deregulation, the Sri Lankan economy has been dominated by the government sector and the common perception among the population is that the government sector is superior to the private sector. This has helped government-owned banks to maintain a substantial market power in the banking sector of the country and to benefit from such an advantageous position. Additionally, Sri Lanka is still a developing country and the financial literacy of the public is still low. As a result, new products and services offered by the private sector banks are not penetrating public minds, and many people are still comfortable with traditional products offered by the government sector banks.

\section{Conclusion}

In this study, we analyse the relationship between diversification and performance of Sri Lankan banks using the data for three types of domestic banks (i.e. GOVU, GOVL and private sector listed banks) for the period from 2001 to 2016. Our initial analyses revealed that, first, the performance of Sri Lankan banks has been significantly improved by their diversification attempts. Second, the performance of government-owned unlisted banks is significantly lower than that of the private sector listed banks while the performance of government-owned listed banks is not dissimilar to that of the private sector listed banks. Third, the performance of Sri Lankan banks has a significant positive influence on the diversification of their sources of income. Finally, government-owned unlisted banks are significantly less diversified than private sector listed banks, while the income diversification of government-owned listed banks is not significantly different from that of private sector listed banks.

When the two-way relationship between diversification and performance was scrutinised by employing the 2SLS technique, we found that a statistically significant bidirectional relationship exists between diversification and performance. We attribute this to the opportunities provided to the banking sector in the post-deregulatory era. However, when this two-way relationship was taken into account, it was found that while private sector banks are significantly more diversified than their government-owned counterparts, both listed and unlisted, their performance is not necessarily superior to government-owned banks. This can be a result of the economic environment and the perception of the public, which has allowed the government-owned banks to entertain significant market power over the private sector banks in the country. 


\section{References}

Baele, L., De Jonghe, O., \& Vander Vennet, R. (2007). Does the stock market value bank diversification? Journal of Banking \& Finance, 31(7), 1999-2023.

Batten, J. A., \& Vo, X. V. (2016). Bank risk shifting and diversification in an emerging market. Risk Management, 18(4), 217-235.

Berger, A. N., Hasan, I., \& Zhou, M. (2009). Bank ownership and efficiency in China: What will happen in the world's largest nation? Journal of Banking and Finance, 33(1), 113-130.

Binh, T. T. D, \& Nguyen, D. P. (2020). Determinants of profitability in commercial banks in Vietnam, Malaysia and Thailand. Journal of Asian Finance, Economics and Business, 7(4), 133143. https://doi.org/10.13106/jafeb.2020.vol7.no4.133

Bonin, J. P., Hasan, I., \& Wachtel, P. (2005). Bank performance, efficiency and ownership in transition countries. Journal of Banking and Finance, 29(1), 31-53.

Claessens, S., Djankov, S., Fan, J. P. H., \& Lang, L. H. P (2002). Disentangling the incentive and entrenchment effects of large shareholdings. Journal of Finance, 57(6), 2741-2771.

DeYoung, R., \& Roland, K. P. (2001). Product mix and earnings volatility at commercial banks: Evidence from a degree of total leverage model. Journal of Financial Intermediation, 10(1), 54-84.

Diamond, D. W. (1984). Financial intermediation and delegated monitoring. Review of Economic Studies, 51(3), 393-414.

Elsas, R., Hackethal, A., \& Holzhauser, M. (2010). The anatomy of bank diversification. Journal of Banking and Finance, 34(6), 1274-1287.

Kaplan, S., \& Weisbach, M.S. (1992). The success of acquisitions: Evidence from divestitures. Journal of Finance, 47(1), 107-139.

Khan A., Hassan, M. K., Maroney, N., Boujlil, R., \& Ozkan, B. (2020). Efficiency, diversification, and performance of US banks. International Review of Economics and Finance, 67(C), 101-117.

Jensen, M. C. (1986). Agency costs of free cash flow, corporate finance, and takeovers. The American Economic Review, 76(2), 323-329.

John, K. \& Ofek, E. (1995). Asset sales and increase in focus. Journal of Financial Economics, 37(1), 105-126.

Laeven, L., \& Levine, R. (2007). Is there a diversification discount in financial conglomerates? Journal of Financial Economics, 85(2), 331-367.

La Porta, R., Lopez-De-Silanes, F., \& Shleifer, A. (2002). Government ownership of banks. Journal of Finance, 57(1), 265-301.

Lee, C-C., Hsieh, M-F., \& Yang, S-J. (2014). The relationship between revenue diversification and bank performance: Do financial structures and financial reforms matter? Japan and the World Economy, 29(C), 18-35.

Lepeti, L., Nys, E., Rous, P., \& Tarazi, A. (2008). Bank income structure and risk: An empirical analysis of European banks. Journal of Banking \& Finance, 32(8), 1452-1467.

Lin, X., \& Zhang, Y. (2009). Bank ownership reform and bank performance in China. Journal of Banking and Finance, 33(1), 20-29.

Mercieca, S., Schaeck, K., \& Wolfe, S. (2007). Small European banks: Benefits from diversification? Journal of Banking \& Finance, 31(7), 1975-1998.

Micco, A., Panizza, U., \& Yañez, M. (2007). Bank ownership and performance. Does politics matter? Journal of Banking and Finance, 31(1), 219-241.

Moudud-UI-Huq, S., Ashraf, B.N., Gupta, A.D., \& Zheng, C. (2018). Does bank diversification heterogeneously affect performance and risk-taking in ASEAN emerging economies? Research in International Business and Finance, 46(C), 342-362.

Pennathur, A. K., Subrahmanyam, V., \& Vishwasrao, S. (2012). Income diversification and risk: Does ownership matter? An empirical examination of Indian banks. Journal of Banking and Finance, 36(8), 2203-2215.

Rossi, S. P. S, Schwaiger, M. S., \& Winkler, G. (2009). How loan portfolio diversification affects risk, efficiency and capitalization: A managerial behavior model for Austrian banks. Journal of Banking \& Finance, 33(12), 2218-2226.

Sarwar, B., Muhammad, N., \& Zaman, N.U. (2020). Diversification, industry concentration, and bank margins: Empirical evidence from an emerging south Asian economy. Journal of Asian Finance, Economics and Business, 7(7), 349-360. https://doi. org/10.13106/jafeb.2020.vol7.no7.349

Stien, J. C. (1997). Internal capital markets and the competition for corporate resources. Journal of Finance, 52(1), 111-133.

Stiroh, K. J. (2004). Diversification in banking: Is noninterest income the answer? Journal of Banking and Finance, 30(5), 2131-2161.

Stiroh, K. J., \& Rumble, R. (2006). The dark side of diversification: The case of U.S. financial holding companies. Journal of Money, Credit, and Banking, 36(8), 853-882.

Tabash, M .I. (2019). An empirical investigation on the relation between disclosure and financial performance of Islamic banks in the United Arab Emirates. Journal of Asian Finance, Economics and Business, 6(4), 27-35. https://doi.org/10.13106/ jafeb.2019.vol6.no4.27

Venzin, M., Kumar, V., \& Kleine, J. (2008). Internationalization of retail banks: A micro-level study of the multinationalityperformance relationship. Management International Review, 48(4), 463-485. 